\title{
Current Status of Mammals and Reptiles at Hub Dam Area, Sindh / Balochistan, Pakistan
}

\author{
ABEDA BEGUM ${ }^{* 1}$, M ZAHEER KHAN $^{2}$, SYED ALI GHALIB², ABDUR RAZZAQ KHAN ${ }^{3}$, \\ AFSHEEN ZEHRA ${ }^{2}$, BABAR HUSSAIN ${ }^{4}$, SAIMA SIDDIQUI ${ }^{4}$ and FOZIA TABBASSUM ${ }^{2}$
}

\author{
${ }^{1}$ Department of Environmental Science, Federal Urdu University of Arts, \\ Science and Technology, Karachi, Pakistan. \\ ${ }^{2}$ Department of Zoology, Faculty of Science, University of Karachi, Karachi, Pakistan. \\ ${ }^{3}$ Halcrow Pakistan (Pvt) limited, Karachi, Pakistan. \\ ${ }^{4}$ Department of Zoology, Federal Urdu University of Arts, \\ Science and Technology, Karachi, Pakistan.
}

http://dx.doi.org/10.12944/CWE.8.3.08

(Received: October 01, 2013; Accepted: November 02, 2013)

\begin{abstract}
During the present study in 2012, a total of twenty four mammalian species were recorded belonging to 5 orders and 10 families; out of these, 8 species are less common, 2 species are rare, while 14 species are common in Hub Dam area. Twenty five reptilian species belonging to 3 orders and 12 families were also recorded from the area. Three species of mammalian Urial (Ovis vignei), Chinkara/Indian Gazelle (Gazella bennettii) and Jungle Cat (Felis chaus), one reptilian species Common Krait (Bungarus caeruleus) were recorded as rare from the study area during 2012. During the present study, nine mammalian species Wild Goat/Sindh Ibex (Capra aegagrus), Urial (Ovis vignei), Chinkara/Indian Gazelle (Gazella bennettii), Indian Hedgehog (Paraechinus micropus), Cape Hare (Lepus capensis), Little Indian Field Mouse (Mus booduga), House Shrew (Sorex thibetanus), Balochistan Gerbil (Gerbillus nanus) and Indian Gerbil (Tatera indica) and two reptilian Warty Rock Gecko (Cyrtodactylus kachhensis) and Banded Dwarf Gecko (Tropiocolotes helenae) were recorded from the area. As regards threats to mammals and reptiles, these are affected by disturbance. Efforts are being made to conserve the important mammals and reptiles particularly in the protected area especially at Hub Dam.
\end{abstract}

Key words: Mammalian and Reptilian Fauna, Rare Species, Status, Protected Areas.

\section{INTRODUCTION}

It is also an important area for Urial and Sind Ibex ${ }^{15}$. In the Khirthar Protected area Complex (KPAC), total of 33 species of mammals has so far been recorded ${ }^{15}$.

Asia is rich in habitats and biodiversity, and correspondingly rich in turtle species ${ }^{12}$. According to IUCN (2009), there are now 1,677 reptiles species have been included on the IUCN Red List, with 293 added in 2009. In total, 469 are threatened with extinction and 22 are already Extinct or Extinct in the wild. Pakistan has 179 species of reptilian fauna consisting of turtles, tortoises, crocodile, gavial, lizards and snakes ${ }^{21}$.

Auffenberg et al., (1989, 1991), Boulenger (1890), Ghalib et al. (1981), Iffat and Auffenberg (1988), Khan (2006), Khan and Mirza (1977), Khan and Nazia (2003), Khan et al. (2005), Mertens (1969), Minton (1966), Rahman et al. (2002), Rahman and Papenfuss (2005) and Iffat (2006, 2009) have contributed some work in the field of herpetofauna of Pakistan. 
Hub dam (25 $\left.15^{\circ} \mathrm{N} 67^{\circ} 07^{\prime} \mathrm{E}\right)$ was constructed on Hub River in 1981, at a distance of $56 \mathrm{~km}$ North of Karachi in Sindh - Balochistan provinces border ${ }^{6}$. Main Dam is 15,640 meters $(\mathrm{m})$ long of which $10,240 \mathrm{~m}$ lies in Sindh while rest in Balochistan ${ }^{13}$. Hub Dam was declared as a Wildlife Sanctuary in 1972 to conserve waterbirds and the indigenous fish Mahsheer (Tor putitora) ${ }^{13}$. Before the creation of the dam, this area was famous among anglers as the habitat of Mahaseer, a game fish $^{6}$. The dam is situated in an area of semi arid and desert with sedimentary rocks. There are a few small islands in the midst of the reservoir. Hub River originates in Kirthar Range of eastern Balochistan and enters the Arabian Sea just west of Karachi. The Hub River separates the provinces Balochistan and Sindh, each of which receives water by a canal from Hub Dam reservoir ${ }^{18}$. The water level in the reservoir fluctuates widely according to rainfall in the water catchment area which extends over 3410 sq. miles. The topography of the upper catchment is sub - mountainous to hilly and plain. The area is generally barren with sparse vegetation at certain locations. The catchment of the Hub reservoir is wholly rain fed. The dam is relatively shallow with maximum depth of $9.6 \mathrm{~m}$. The water has relatively high concentration of dissolved salts of sulphates, sodium and chloride and dissolved oxygen which results into high greater primary and secondary production. The climate of the area is predominantly arid and with an average annual rainfall of less than 200 millimeters $(\mathrm{mm})$. The temperature often exceeds 36 Celsius $\left({ }^{\circ} \mathrm{C}\right)$ during summer 6 . A Forest Plantation and Recreational Park of about 80 ha has been established by Balochistan Forest Department ${ }^{6}$.

Khan et al., (2012a), reported about the fauna and the environmental conditions of Hub Dam Wildlife Sanctuary area of KPAC, and reported to have encountered 16 species of mammals, 160 species of birds, 23 species of reptiles, 03 species of amphibians, 29 species of fishes, and 25 species of plants ${ }^{13}$.

The objective of the present study was to determine the habitat and current status of the mammals and reptiles at Hub Dam Wildlife Sanctuary.

\section{MATERIAL AND METHODS}

\section{Study Areas}

Area near Spill way (N 25 $17^{\prime} 23.2$, E $67^{\circ}$ $05^{\prime}$ 55.6), having rocky slopes with spare vegetation and reservoir area, Main Dam area (N 25 $5^{\circ} 14^{\prime} 35.5$, E $67^{\circ} 06^{\prime} 45.8$ ), wetland area, Hub Canal ( $\mathrm{N} 25^{\prime}$ $14^{\prime} 26.6$, E $67^{\circ} 06^{\prime} 48.6$ ), rocky, agricultural and plain area, Shallow water area towards Khar Center (N 25 $5^{\circ} 14^{\prime} 55.3$, E $67^{\circ} 08^{\prime} 56.3$ ), agricultural, marshes and rocky, Usman Qalandria (N 25 $17^{\circ}$ 38.5, E $67^{\circ} 05^{\prime} 94.2$ ), rocky and plain area, Robo

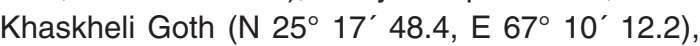
rocky, flat and plain area, Robo Goth (N 25 $14^{\circ}$ 48.1, E $\left.67^{\circ} 09^{\prime} 32.5\right)$, rocky and plain area, Rest House Side (N 25 15'40.1, E $67^{\circ} 05^{\prime}$ 54.8), rocky and wetland area, Plantation Area ( $25^{\circ} 16^{\prime} 32.3$, $\mathrm{E} 67^{\circ} 06^{\prime} 39.1$ ), forest, rocky and wetland area and Bund Murad (N $26^{\circ} 05^{\prime} 77.4$, E $69^{\circ} 09^{\prime} 39.0$ ), rocky and wetland area.

\section{Mammals and Reptiles}

Various methods or survey techniques have been employed for the observation of mammals and reptiles. For the identification of reptiles, Minton (1966) ${ }^{16}$ was used.

Mammalian survey: For observing mammals, field trips were mostly arranged early in the morning and different direct and indirect observation methods were applied. For diurnal mammals, direct observation methods were used while for nocturnal large mammals, indirect observation methods such as, observing pug marks, fecal material, territory marking signs etc., were used. Most of the small mammals, like rodents, lagomorphs etc., were directly observed in the day time whereas for nocturnal small mammals different live traps were used.

\section{Reptilian survey}

To study the reptilian fauna, field visits were carried out between 10:00 am to 3:00 pm. Stone turning, looking at and through bushes, observing large trees keenly, walking along streams, and turning scattered debris accumulated under trees were various means used to find lizards and snakes. Fast moving Agamid lizards were collected by striking with stick. Some specimens were pulled out with the help of long forceps from 
crevices in stones while a few were collected by hand from under the stones.

\section{RESULTS AND DISCUSSION}

24 species of mammals belonging to 5 order and 10 families were recorded during the present study (Table 1), which include the key species such as Sindh Ibex or Sind Wild Goat (Capra aegagrus), Urial (Ovis vignei) (Fig. 2), Chinkara (Gazella bennettii) (Fig. 3), along with Red Fox (Vulpes vulpes), Indian Fox (Vulpes bengalensis), Jungle Cat (Felis chaus), Indian Hare (Lepus nigricollis), Indian Jackal (Canis aureus), Five striped palm Squirrel (Funambulus pennanti) and Cairo Spiny Mouse (Acomys cahirinus) which were sighted and counted during the present study.

On the basis of percentage composition and species richness, order Rodentia was dominant (10 species) followed by Sciuridae, Hystricidae and Soricidae (1species each) and

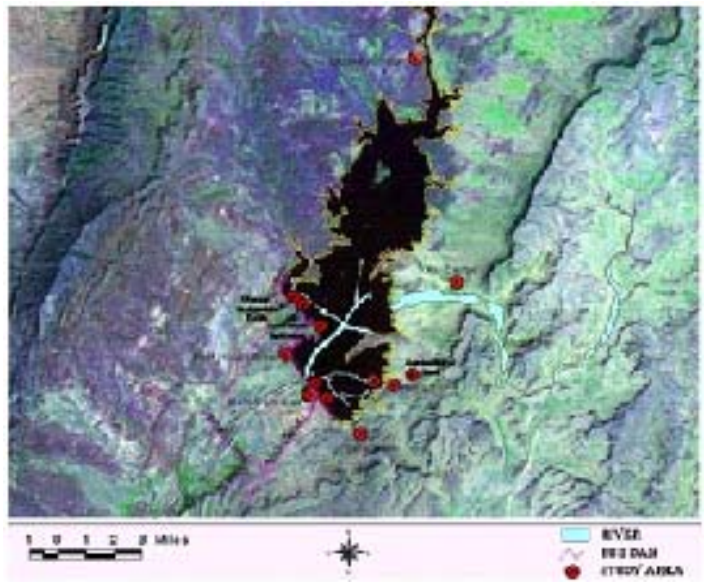

Fig. 1: Satellite image of Study Areas

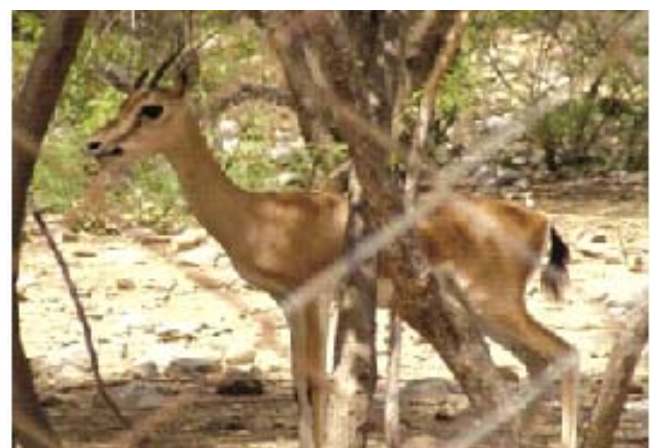

Fig. 3: Chinkara (Gazella bennettii)
Muridae (7species), next order Carnivora represented (6 species) followed by Felidae (1species), Canidae (3 species) and Herpestidae (2 species), Artiodactyla represented 3 species by Bovidae, Insectivora 2 species by Erinaceidae, Lagomorpha 2 species by Leporidae, and Chiroptera 1 species by Pteropidae (Fig4). During the present investigation the order of dominance is as follows:

Rodentia $>$ Carnivora $>$ Artiodactyla $>$ Insectivora = Lagomorpha $>$ Chiroptera

Three species of mammals viz. Urial, Chinkara / Indian Gazelle and Jungle Cat were recorded as rare from the study area during 2012. Sixteen species of mammals belonging to 6 orders and 10 families were recorded from the study area ${ }^{13}$. Nine species of mammals recorded during the present study viz. Wild Goat/Sindh Ibex (Capra aegagrus), Urial (Ovis vignei), Chinkara/Indian Gazelle (Gazella bennettii), Indian Hedgehog

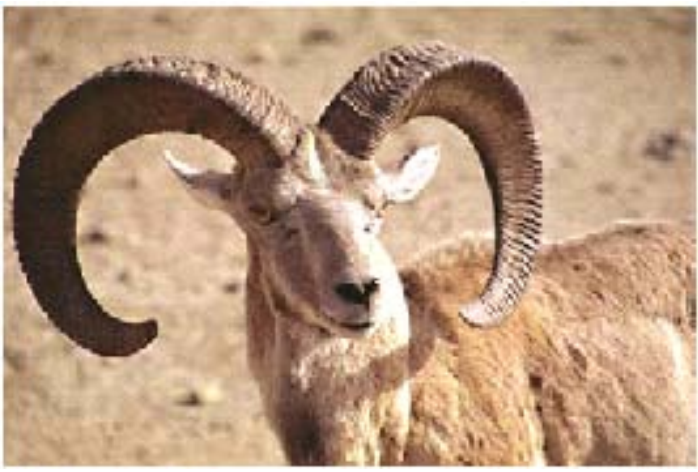

Fig. 2: Urial (Ovis vignei) (source: Sindh Wildlife Department)

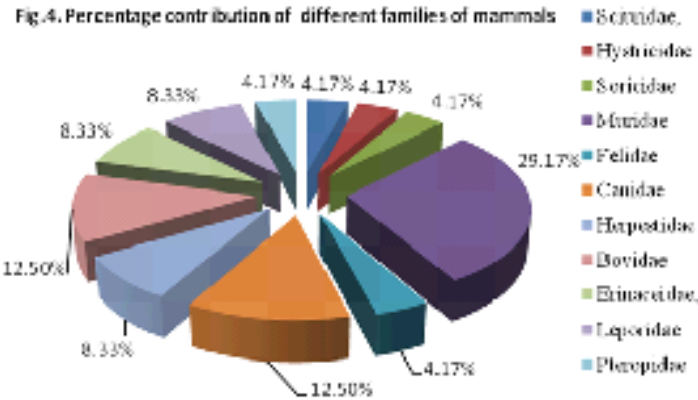

Fig. 4: Percentage contribution of different families of mammals 


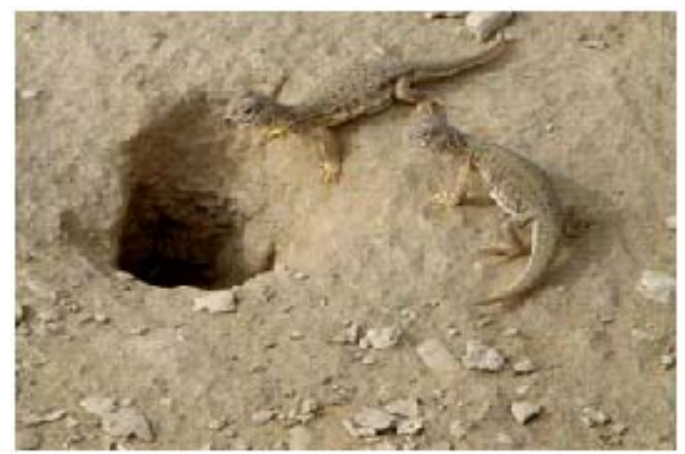

Fig. 5: Indian Spiny - tailed Lizard

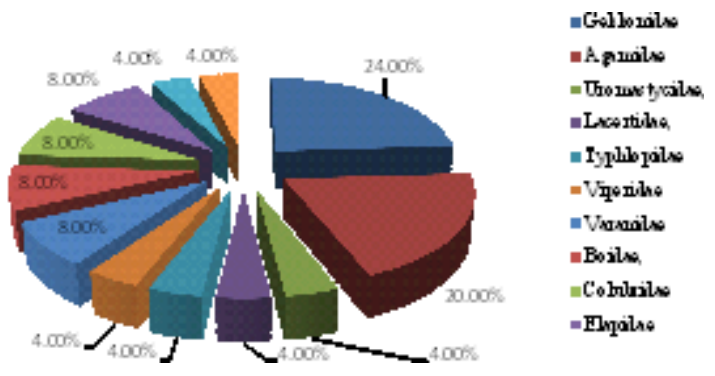

Fig. 7: Percentage contribution of different families of Reptiles

(Paraechinus micropus), Cape Hare (Lepus capensis), Little Indian Field Mouse (Mus booduga), House Shrew (Sorex thibetanus), Balochistan Gerbil (Gerbillus nanus) and Indian Gerbil (Tatera indica) were not recorded previously ${ }^{13}$.

The common species of the mammals found in the Keenjhar lake include Palm Squirrel (Funambulus pennanti), Indian Gerbil (Tatera indica), Indian Desert Jird (Meriones hurrianae), House Mouse (Mus musculus), House Rat (Rattus rattus), Asiatic Jackal (Canis aureus) and Indian Porcupine (Hystrix indica) ${ }^{14}$. During the present study, all these species of Sindh were observed as a common species from the area. One main specie Indian Pangolin (Manis crassicaudata), although previously recorded from the area, was not recorded or reported during the present study while it was reported as a less common during the Study in $2007-2010^{13}$. There is lot of disturbance to the wild animals due to movement of local people in the area $^{15}$. During the present study, the main threats to the mammals of Hub Dam were documented viz; habitat degradation, weak enforcement of wildlife laws and lack of public awareness.

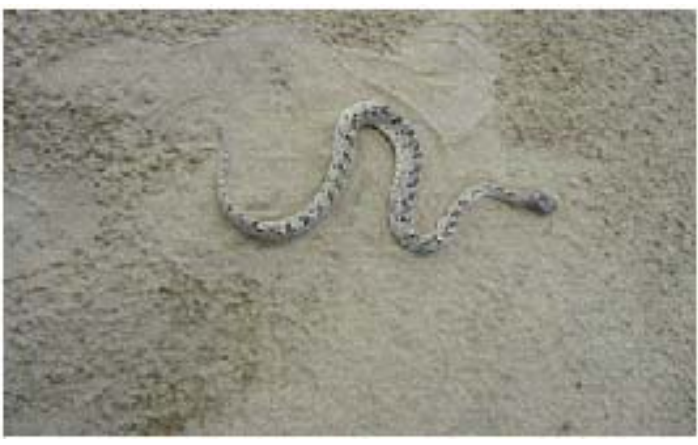

Fig. 6: Saw Scaled Viper

A Total of twenty seven reptilian species was recorded from Karachi areas including 3 turtles, 9 lizards and 15 snakes $^{12}$. In Pakistan, reptiles are a blend of Palaearctic, Indo- Malayan and Ethiopian forms ${ }^{4} .23$ species of reptiles were reported from Hub Dam area ${ }^{13}$. During the present study, 25 species of reptiles belonging to 3 order and 12 families were recorded from the study area (Table 2). Marsh Crocodile (Crocodylus palustris), Brilliant Agama (Trapelus agilis), Indian Spiny - tailed Lizard (Uromastix hardwickii) (Fig.5), Indian Monitor Lizard (Varanus bengalensis), Indian Cobra (Naja naja), Indian Fringed toed Lizard (Acanthodactylus cantoris), Indian Desert Monitor (Varanus griseus) Indian Sand Boa (Eryx johnii), Common Krait (Bungarus caeruleus) and Saw Scaled Viper (Echis carinatus) (Fig.6) are the important species of reptiles of the area.

On the basis of percentage composition and species richness, order Squamata was dominant (23 species) followed by Gekkonidae (6species), Agamidae (5species), Uromastycidae, Lacertidae, Typhlopidae and Viperidae (1 specie each), Varanidae, Boidae, Colubridae and Elapidae (2 species each), while Chelonia and Crocodilia represented 1 specie by Emydidae and Crocodylidae respectively (Fig7). During the present investigation the order of dominance is as follows:

\section{Squamata $>$ Chelonia $=$ Crocodilia}

One of the reptilian specie Common Krait (Bungarus caeruleus) was recorded as rare from the study area. The common species of reptiles of the area include Spotted Indian House Gecko 


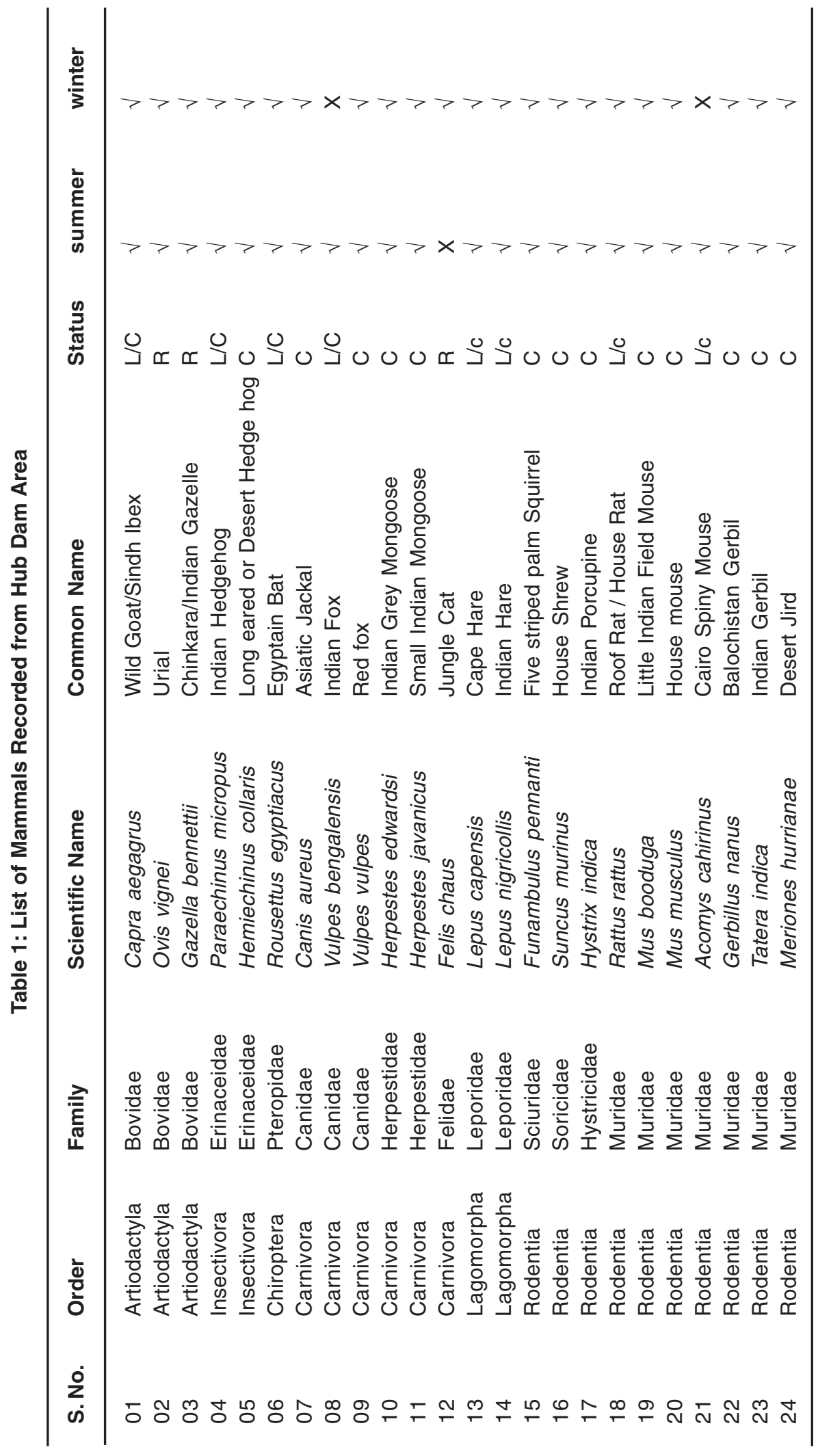




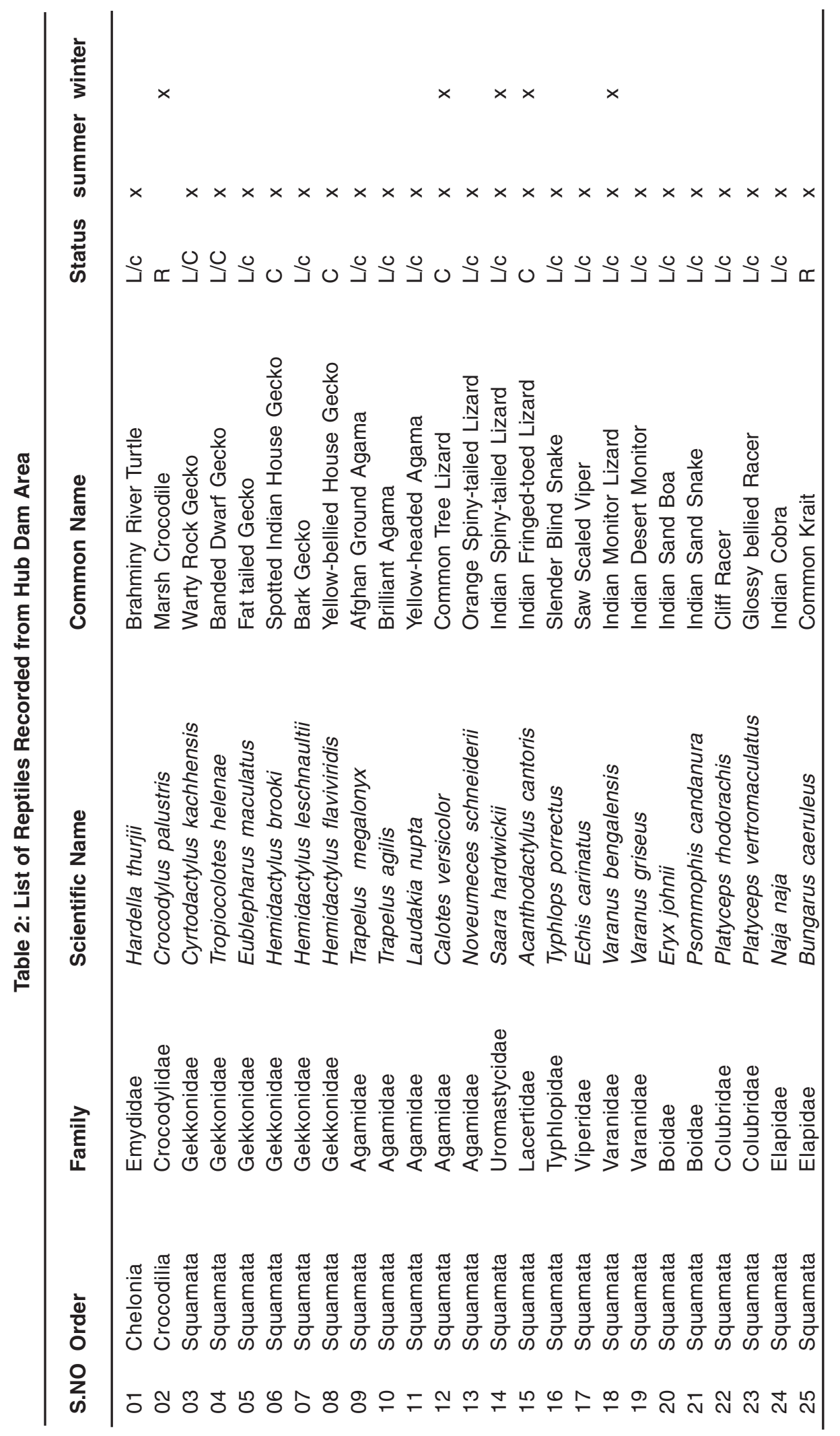


(Hemidactylus leschnaultii), Yellow-bellied House Gecko (Hemidactylus flaviviridis), Common Tree Lizard (Calotes versicolor) and Indian Fringed-toad Lizard (Acanthodactylus cantoris). Two reptilian species viz. Warty Rock Gecko (Cyrtodactylus kachhensis) and Banded Dwarf Gecko (Tropiocolotes helenae) were recorded during present study but not reported previous by ${ }^{13}$.

The key species of the Haleji Lake. include; Indian Monitor (Varanus bengalensis), Desert Monitor (Varanus griseus), and Spiny-tailed Lizard (Saara hardwickii), while Marsh Crocodile (Crocodylus palustris) is recorded as a threatened species $^{14}$. During the present study, these all species of Sindh were recorded from the present selected areas.

All mammalian species were reported during summer except Jungle Cat; and Indian Fox and Cairo Spiny Mouse were not able to report during winter while most of the reptilian species were reported during summer and Marsh Crocodile, Common Tree Lizard, Indian Spiny-tailed Lizard, Indian Monitor Lizard and Indian Fringed-toed Lizard were reported during winter (Table 1\& 2).

Changes in land use practices, habitat modification, hunting, unregulated fishing, overexploitation, conflicts with Wild Boars, Jackals, Fox spp. and snakes with local community, and trapping of mongoose spp., Cobra, Dhaman and Monitor lizard, etc. were major threats to the wildlife of the reservoir and surroundings ${ }^{19}$. During the present study, the unregulated fishing, overexploitation, and hunting have been observed but no sever threats are observed for reptiles species.

Like Khar Center, here in the Karchat area local communities have been using the same point for the collection of drinking water and due to the movement of people in the area, wild animals have been disturbed. There is competition for grazing between the domestic livestock and the wild animals. There is a lot of disturbance to the wild animals due to movement of local people in the area.

\section{CONCLUSION}

On the basis of observations, the threats to the mammals of Hub Dam were documented viz; Habitat Degradation, Weak Enforcement of Wildlife Laws and lack of Public Awareness. No severe threats to the reptiles of the area were reported. It is concluded that the area is rich in diversity. It is suggested that the management plan of the reservoir should be implemented in its true letter and sprit. Public awareness programmes may be taken up for the conservation and sustainable utilization of the natural resources.

\section{REFERENCES}

1. Auffenberg, W., Rahman, H., Iffat, F. and Perveen, Z., A study of Varanus flavescens (Sauria Varanidae). Bombay Nat. Hist. Soc. 86:286-307 (1989).

2. Auffenberg, W. and Rahman, H. 1991., Studies on Pakistan Reptiles. Pt. I. The genus Echis (Viperidae). Bull. Florida Mus. Nat. Hist. 35(5): 263-314 (1991).

3. Boulenger, G.A., Fauna of British India, including Ceylon and Burma: Reptile and Batrichia, London (1890).

4. Fatima F. Distribution and status of freshwater turtles in Sindh. Ph.D. Thesis, Department of Zoology, University of Karachi (2008).

5. Ghalib, S.A., Rahman, H., Iffat, F. and Hasnain, S.A., A Checklist of Reptiles of Pakistan. Rec. Zool. Surv. Pakistan. 8:37-59
(1981).

6. Ghalib, S.A., Hasnain, S.A. and Khursheed, S.N., Observations on the Avifauna of Hub Dam. Pak.J. Zool. 32(1): 27 - 32 (2000).

7. Iffat, F. and Auffenberg, W., New Reptile Records for Pakistan, Agama minor. Sauria. 19:61 (1988). IUCN., Extinction Crisis Continues Apace (2009).

8. Khan, M.S. and Mirza, M.R., An annotated Checklist and key to the Reptiles of Pakistan Part II: Sauria (Lacertilia). Biologia. 23:41-64 (1977).

9. Khan, M.Z. and Nazia, M., Current Population Status of Diurnal Lizards of Karachi, Pakistan. Russian Journal of Herpetology. 10(3):207210 (2003).

10. Khan, M.Z., Hussain, B. and Ghalib, S.A., 
Current Status of the Reptilian Fauna along Karachi Coast with Special Reference to Marine Turtles. J. nat. hist. wildl. 4(2):127-130 (2005).

11. Khan, M.S., Amphibians and Reptiles of Pakistan. Kriegar Publishing Company, Malabar, Florida. pp. 311 (2006).

12. Khan, M.Z., Hussain, B., Ghalib. S.A, Zehra. A., and Mahmood, N., Distribution, pollution status and environmental impacts on reptiles in Manora, Sandspit, Hawkesbay and Cape Monze Areas of Karachi Coast. Canadian Journal of Pure and Applied Science. 4(1):1053-1071 (2010).

13. Khan, M.Z., Begum, A., Ghalib. S.A, Khan. A.R., Yasmeen. R., Siddqui. T.F., Zehra. A., Abbas, D., Tabassum. F., Siddqui. S., Jabeen. T. and Hussain. B., Effects of Environmental Pollution on Aquatic Vertebrate Biodiversity and Inventories of Hub Dam: Ramsar Sites. Canadian Journal of Pure and Applied Science. 6(2): 1913-1935 (2012a).

14. Khan, M.Z., Abbas, D., Ghalib. S.A, Yasmeen. R., Siddqui. S., Mehmood Nazia., Zehra. A., Begum, A., Jabeen. T., Yasmeen, G. and Latif, T.A, Effects of envirobmental pollution on aquatic vertebrates and inventories of Haleji and Keenjhar lakes: Ramsar Sites. Canadian Journal of Pure and Applied Science. 6(1):1759-1783 (2012b).

15. Khan, M.Z., Ghalib. S.A, Khan. A.R., Zehra. A., Yasmeen. R., Hussain. B., Siddqui. S., Abbas, D., Fatima. F., Begum, A., Jabeen. T.,
Tabassum. F., and Hashmi. M.U.A., Current Habitat, Distribution and Status of the Mammals of Khirthar Protected Area Complex, Sindh.7(2):2347-2356 (2013).

16. Minton, S.A., A Contribution to the Herpetology of West Pakistan. Bull. Amer. Mus. Nat. Hist. 134:24-184 (1966).

17. Mertens, R., Die Amphibian and reptilian, West Pakistan. Stuttgarter Beiter Natur Kunde. 197:1-96 (1969).

18. Qaimkhani, M.I., Kamil, M., Ambrat \& Khan, G., Water irrigation chemistry of underground water in hub valley KarachiPakistan. Journal of Chemical Society of Pakistan. 27(6): 585589 (2005).

19. Rais, M., Khan, M.Z., Abbass, D., Akber, G., Nawaz, R and Saeed-ul-Islam, A Qualitative Study on Wildlife of Chotiari Reservoir, Sanghar, Sindh, Pakistan, Pakistan J. Zool.,43(2)237-247 (2011).

20. Rehman, H., Ahmad, S.I. and Fakhri, S., Home Range and Growth Rate of Fringe toad Sand Lizard (Acanthodactylus cantoris) at Hawksbay area, Karachi. Rec. Zool. Surv. Pakistan. 14:49-54 (2002).

21. Rehman, H. and Iffat, F., A Revised Checklist of Reptiles of Pakistan. Records Zool. Surv. Pak. 13: 1 - 7 (1997).

22. Rehman, H. and Papenfuss, T.J., An up-todate Checklist of Reptilian Fauna of Balochistan. J. nat. hist. wildl. 4:131-136 (2005). 